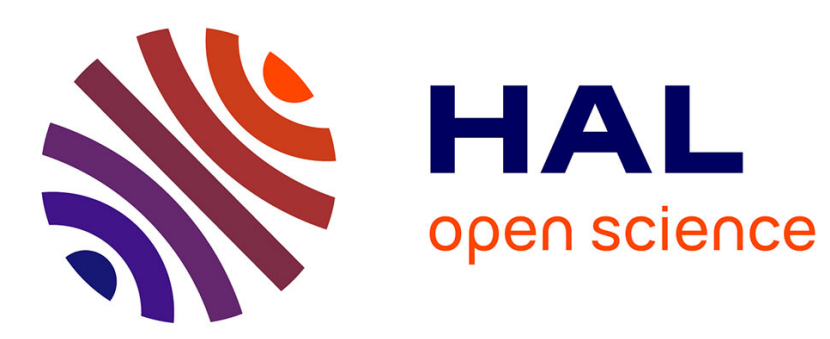

\title{
New method for environmental monitoring in armed conflict zones: a case study of Syria
}

\author{
Samira Mobaied, Jean-Paul Rudant
}

\section{To cite this version:}

Samira Mobaied, Jean-Paul Rudant. New method for environmental monitoring in armed conflict zones: a case study of Syria. Environmental Monitoring and Assessment, 2019, 191 (11), pp.643. 10.1007/s10661-019-7805-5 . hal-02340107

\section{HAL Id: hal-02340107 https://hal.sorbonne-universite.fr/hal-02340107}

Submitted on 30 Oct 2019

HAL is a multi-disciplinary open access archive for the deposit and dissemination of scientific research documents, whether they are published or not. The documents may come from teaching and research institutions in France or abroad, or from public or private research centers.
L'archive ouverte pluridisciplinaire HAL, est destinée au dépôt et à la diffusion de documents scientifiques de niveau recherche, publiés ou non, émanant des établissements d'enseignement et de recherche français ou étrangers, des laboratoires publics ou privés. 
New Method for Environmental Monitoring in Armed Conflict Zones

A case study of Syria

Samira MOBAIED (1), Jean-Paul RUDANT (2)

Cite this article as: Mobaied, S. \& Rudant, JP. Environ Monit Assess (2019) 191: 643. https://doi.org/10.1007/s10661-019-7805-5

(1) Sorbonne Université, Muséum national d'Histoire naturelle, IRD, Patrimoines locaux, environnement et globalisation (PALOC, UMR 208), 57 rue Cuvier, Case Postale 26, 75231 Paris cedex 05, France e-mail: mobaied@mnhn.fr

(2) LaSTIG -UPEM-IGN - Cité Descartes - 5, boulevard Descartes - Champs-Sur-Marne - 77454 Marne-La-Vallée Cedex 2 - France e-Mail: rudant@univ-mlv.fr

\begin{abstract}
:
Today, armed conflict affects some twenty countries, covering an area making up $11 \%$ of the surface area of the Earth. Any degradation of nature in these areas represents a harmful depletion of the world's natural heritage. Despite this, environmental issues are neglected during these periods of conflict, considered secondary to the urgency of restoring peace and safeguarding human life. Yet their consequences are potentially severe. In these areas, it is future generations who will suffer the effects of the current devastation for a very long time.

In this context, the method developed in this study, named (Geographic Information System) for Environmental Monitoring in Wartime, can be used to calculate a risk indicator for environmental degradation, spatial monitoring and risk management. This will make it possible to identify the main threats to protected areas, catalogue the damage caused to the environment by armed conflicts, and create a dynamic risk map. In this paper, GIS-EMW has been applied to calculate a risk indicator for environmental degradation in Syria.
\end{abstract}

Keywords: Method; Environmental Monitoring; Armed Conflict; Syria; GIS, Environmental Index; Risk map

\title{
Introduction:
}

Today, armed conflict affects some twenty countries. The relationship between humankind and nature is changing radically in these areas of armed conflict; extreme circumstances of lack of food, medicine, drinking water and sanitation forces mankind to develop a different relationship with its environment. Any degradation of nature in these areas represents a 
harmful depletion of the world's natural heritage. Despite this, environmental issues are neglected during these periods of conflict, considered secondary to the urgency of restoring peace and safeguarding human life. Yet their consequences are severe and their damage irreversible ${ }^{1}$. In these areas, it is future generations who will suffer the effects of the current devastation for a very long time.

Currently, scientists' intervention is limited to assessing damage in post-conflict periods. Viewpoints around these issues need to evolve in order to develop strategies and tools for the monitoring and active protection of the environment, of nature reserves, and of biodiversity in armed conflict zones in times of war. Geographic information systems, remote sensing and spatial modelling now offer new potential for understanding and analysing observations concerning armed conflict's impact on nature, in order to intervene and prepare better for the post-conflict period. These tools will also be used to document breaches of environmental regulations in real time.

In this context, the method developed can be used to calculate a risk indicator for environmental degradation, spatial monitoring and risk management. This will make it possible to identify the main threats to protected areas, catalogue the damage caused to the environment by armed conflicts, and create a dynamic risk map.

This risk indicator takes account of the conservation priority levels of the area concerned, the site's level of degradation risk, and the ecological services it offers to humans.

Calculating this risk makes it possible to identify those areas with the highest environmental degradation risk, and to determine the best measures that should to be taken.

This methodology could be used to inform a decision support tool coupled with a GIS (Geographic Information System) for Environmental Monitoring in Wartime (i.e. a GISEMW) with a view to controlling environmental damage in armed conflict zones and to propose the intervention strategies needed to limit this damage and plan a rapid resumption of monitoring, focusing on the conservation of biodiversity and natural resources during the post-conflict reconstruction phase.

These tools will also be used to identify the services nature provides to mankind, and the changes mankind brings to its immediate environment in these zones, in order to propose

\footnotetext{
${ }^{1}$ When many species are in danger of becoming extinct, when damage causes irreversible degradation of the fragile ecosystems, when natural resources are irretrievably destroyed or contaminated.
} 
solutions and eco-aware approaches that meet the needs of mankind in these extreme conditions, while maintaining a balanced relationship with nature.

\section{Method:}

Objective: Draw up a map that shows the levels of potential threats from risks of degradation in the protected areas according to several indices. All of this will form part of a GIS in a 10 $\mathrm{km}$ analysis grid, in terms of spatial accuracy.

At each site, the natural habitats will be categorised at site-level according to the global standard Land Cover Classification System (LCCS), developed by the United Nation's Food and Agriculture Organization (FAO), and the United Nations Environment Program (UNEP). Three types of index will be collected.

The first type of index depends on the degree of conservation priority of the natural habitat (directly correlated to the environment's biodiversity).

The second type of index depends on the level of risk of degradation to the site due to armed conflict.

The third index is designed to evaluate ecosystem services with a view to determining which benefits, goods and services can be directly or indirectly derived from ecosystems by humans. The nature of the indices are specified below:

Group I indices: Conservation Priority

Index 1: Local-Level Rarity of natural habitat (R). For each analysis window, this index takes the maximum value of 1 when the habitat is rare, here defined as marginal, declining and threatened habitats (Rameau, 1995). This index will be evaluated by an expert according to available bibliographical sources. This index takes the minimum value of 0.0001 when there are no rare habitats within the area concerned.

Index 2: Surface Area of Habitat (S). For each analysis window, this index is to be assigned the maximum value of 1 when the surface area of a rare natural habitat is less than double the minimum required for habitat maintenance. This index will be evaluated by an expert according to available bibliographical sources. This index takes the minimum value of 0.0001 when the surface area of a rare natural habitat is more than double the minimum required for habitat maintenance.

Index 3: Presence of Threatened Plant \& Animal Species (Sp). This index takes the maximum value of 1 when endangered species occur within the analysis cell. This index takes the minimum value of 0.0001 when no threatened species occur within the analysis cell. 
Group II indices: Degradation risks relating to armed conflicts are subject to three essential factors (i.e. space, time and damaging effect)

Index 4: Proximity to Combat Zones (Comb). This index corresponds to how far away the combat zones are located in relation to the habitat, where the value 0.0001 is to be assigned when there are no combat zones nearby (i.e. within a radius of $10 \mathrm{~km}$ ). This index takes the value 1 if the pixel occurs within a combat zone, otherwise it is to be assigned the value 0.0001 .

Index 5: Proximity to Illegal Oil Drilling Sites or Unauthorised Extraction of Minerals (EXT1). A value of 1 is to be assigned to each analysis cell when the site is being used for illegal mineral extraction (i.e. within a radius of $10 \mathrm{~km}$ ). This value is based on the proximity of the pollution caused by either of the illegal extraction types, otherwise it takes the value 0.0001 .

Index 6: Proximity to Refugee Camps. The value 1 is to be assigned at each analysis window when refugee camps are located nearby, so as to take account of the exploitation of biological resources (EXT2) e.g. collection of firewood (Chechabo 2011) within each site. It takes the value 0.0001 when there are no refugee camps in the vicinity.

Index (t) accounts for Time, which takes a value of 0.01 for each day of fighting occurring within the area, and takes the value 1 when there have been 100 or more days of fighting. Group III: Ecological Service indices (ES):

Group III indexes are to be assigned the value 0.0001 if the area does not offer any of the services concerned by this index, the value 1 if the area does offer the ecological services listed (Maresca et al. 2011), or the value 0.5 if the area offers at least one of the ecological services listed.

Index 7: Life Support Services (LS) offered by the natural area are:

- Primary production

- Soil formation

- $\quad$ Nutrient cycle

Index 8: Regulatory Services (RS) offered by the natural area are:

- Regulation of the hydrologic cycle

- Soil regulation

- Regulation of chemical elements

- Species regulation

- Climate regulation

Index 9: Abstraction \& Supply Services (AS) and Goods offered by the natural area 
- Water

- $\quad$ Energy

- $\quad$ Food

- Biodiversity

Index 10: Socio-Cultural Services (SS):

- Employment

- $\quad$ Scientific / Educational services

- Leisure activities / Entertainment

- $\quad$ Landscape \& Living environment

- $\quad$ Aesthetics \& Spirituality

Stage 2: Merging of results to develop a comprehensive index.

For any given geographic grid cell, an environmental monitoring index in armed conflict zones is defined (image 1)

$$
\text { EM Conflict }=\frac{(C P I+I D+E S) * t}{3}
$$

Where CPI is the Conservation Priority Index for that grid cell. This is calculated using the three indices $\mathrm{R}, \mathrm{S}$ and $\mathrm{Sp}$.

$$
C P I=\frac{R+S+S p}{3}
$$

ID is the Degradation Risk Index for each grid cell. This is calculated using the three indices.

$$
I D=\frac{C o m b+E x t 1+E x t 2}{3}
$$

ES is the Ecological Services Index

$$
E S=\frac{L S+R S+A S+S S}{4}
$$


Index ( $\mathrm{t}$ ): This value approximates 0 when the harmful effects are occasional, and takes the value 1 when the damaging effects have affected the site for at least 100 days.

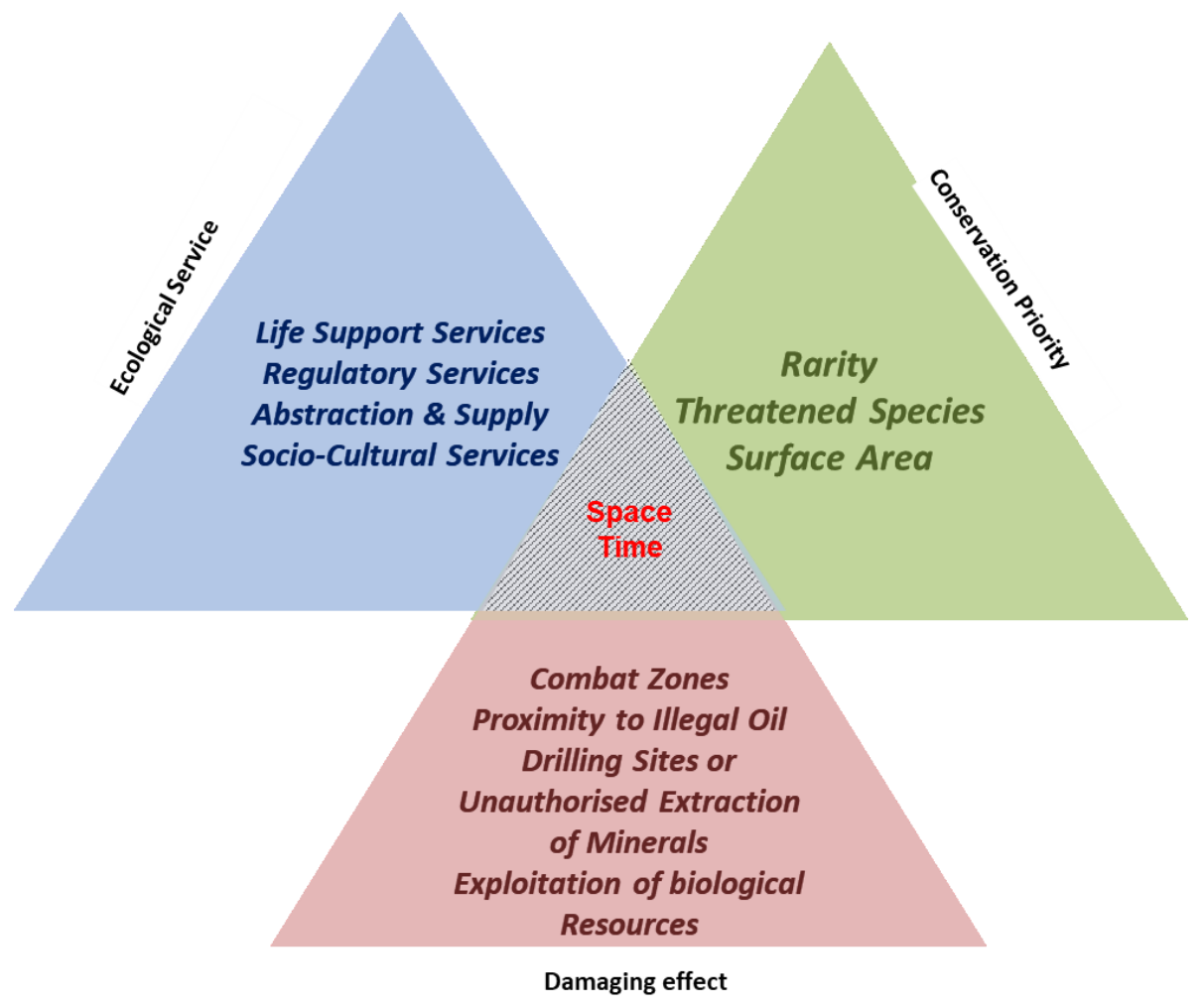

Image1 : Components of the comprehensive EMC Index (Environmental Monitoring Index in Armed Conflict Zones)

\section{Case Study, Syria:}

The armed conflict in Syria, which has been going on now for about 8 years, has had significant negative impacts on the environment. Failure to comply with international conventions for the protection of world natural heritage in wartime has led to serious environmental degradation and destruction. In this context, the EMC Index was calculated for Syria divided into $2454(10 \times 10 \mathrm{Km})$ grid cells. The UTM coordinates (WGS84) of Syria are: Zone 37S E: $499708.67 \mathrm{~N}: 3851094.3$

\section{The Different Indices:}

\section{Conservation Priority Index (CPI):}


The Conservation Priority Index was calculated using indices R, S and $\mathrm{Sp}$, where natural reserve areas in Syria were considered locally rare natural habitats containing threatened plant and animal species; the map of nature reserves in Syria was used (Mobaied, 2016).

The minimum surface area indicating the susceptibility of a habitat to degradation caused by events such as armed conflict has been estimated at 0.5 hectares for forests as well as land use in arid zones (FAO 2012, FAO, 2017). For the nature reserve relating to the Marine Ecosystem, and in the absence of a definition in terms of the ideal size for marine protected areas (Brennan Jacot, 2009), 1000 ha was considered to be more than double the minimum required for habitat maintenance. One hectare was considered the minimum surface area required for maintaining breeding areas.

The ICP was calculated for each grid cell (Map1).

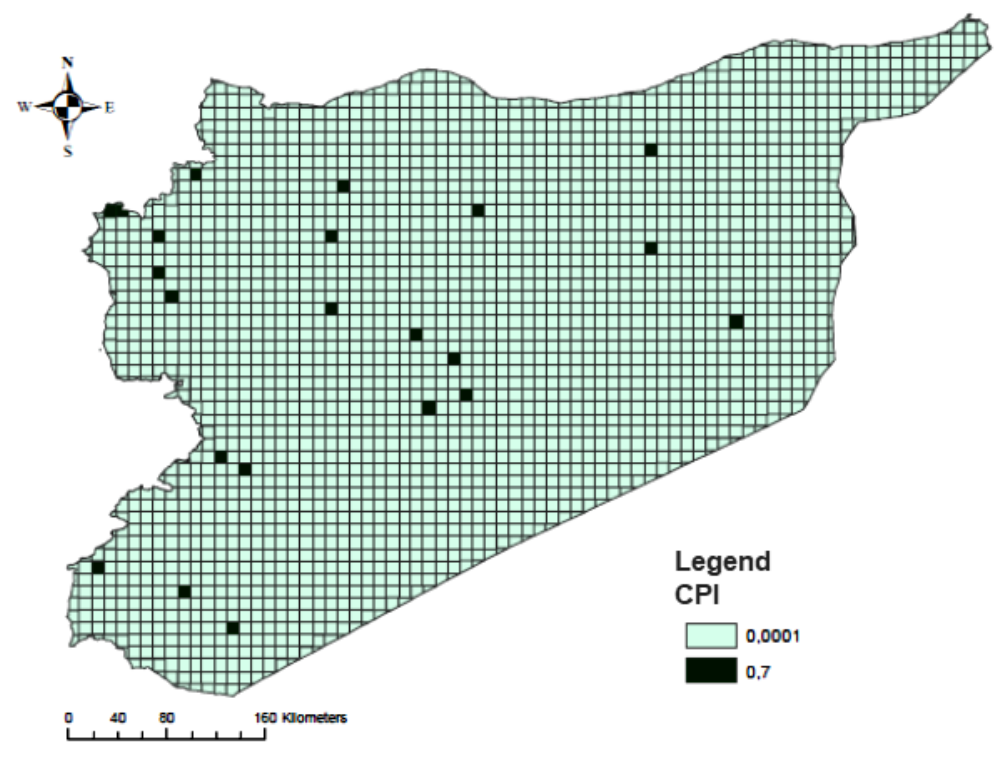

Map1: Conservation Priority Index (CPI) Map in Syria

\section{Degradation Risk Index (DI)}

The Degradation Risk Index was calculated using the three indices - Proximity to Combat Zone (Comb), Proximity to Illegal Oil Extraction Sites (EXT1), Proximity to Refugees Camps (EXT2).

Comb was calculated using Conflict Data for the Syrian Arab Republic, collated by the Armed Conflict Location \& Event Data Project (ACLED)), which records data on fighting and bombing in Syria. (ACLED, 2019) 
The Proximity to Illegal Oil Extraction Sites Index, EXT1, was calculated using maps showing illegal oil drilling sites in Syria (IEA, 2014 and Financial times, 2016)

The Proximity to Refugee Camps Index, EXT2, was calculated using maps showing the location of refugee camps (US Department of State Humanitarian Information Unit, 2014, and Relief Works Agency, 2018).

The Degradation Risk Index was calculated for each grid cell (Map2).

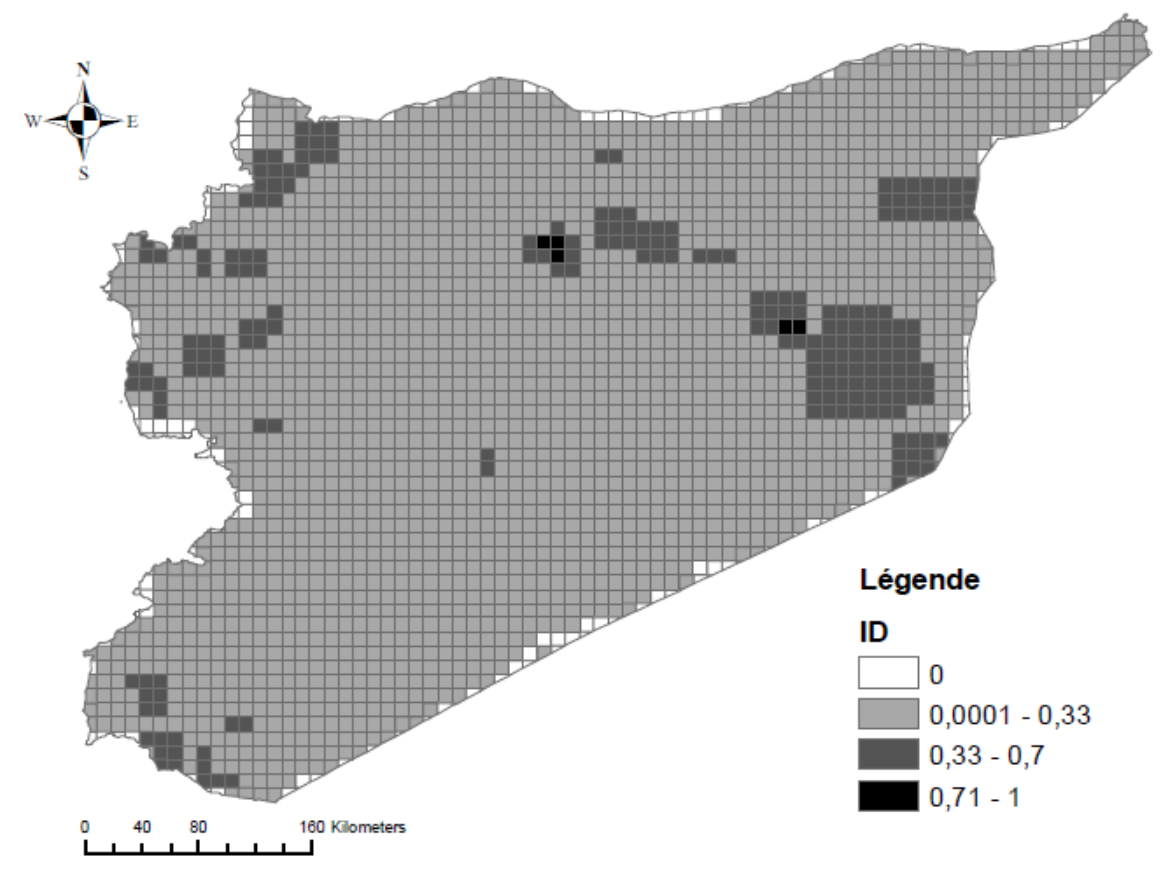

Map 2: Degradation Risk Index (DI) Map in Syria

\section{Ecological Services Index (ES)}

For each of the grid cells, the natural habitats in Syria were classed according to the FAO's 2015 Land Cover Classification System (LCCS) (Di Gregorio, 2016) (Map3). A value for the Ecological Services Index (SE) was assigned to each habitat type (Map 4, Table 1) 


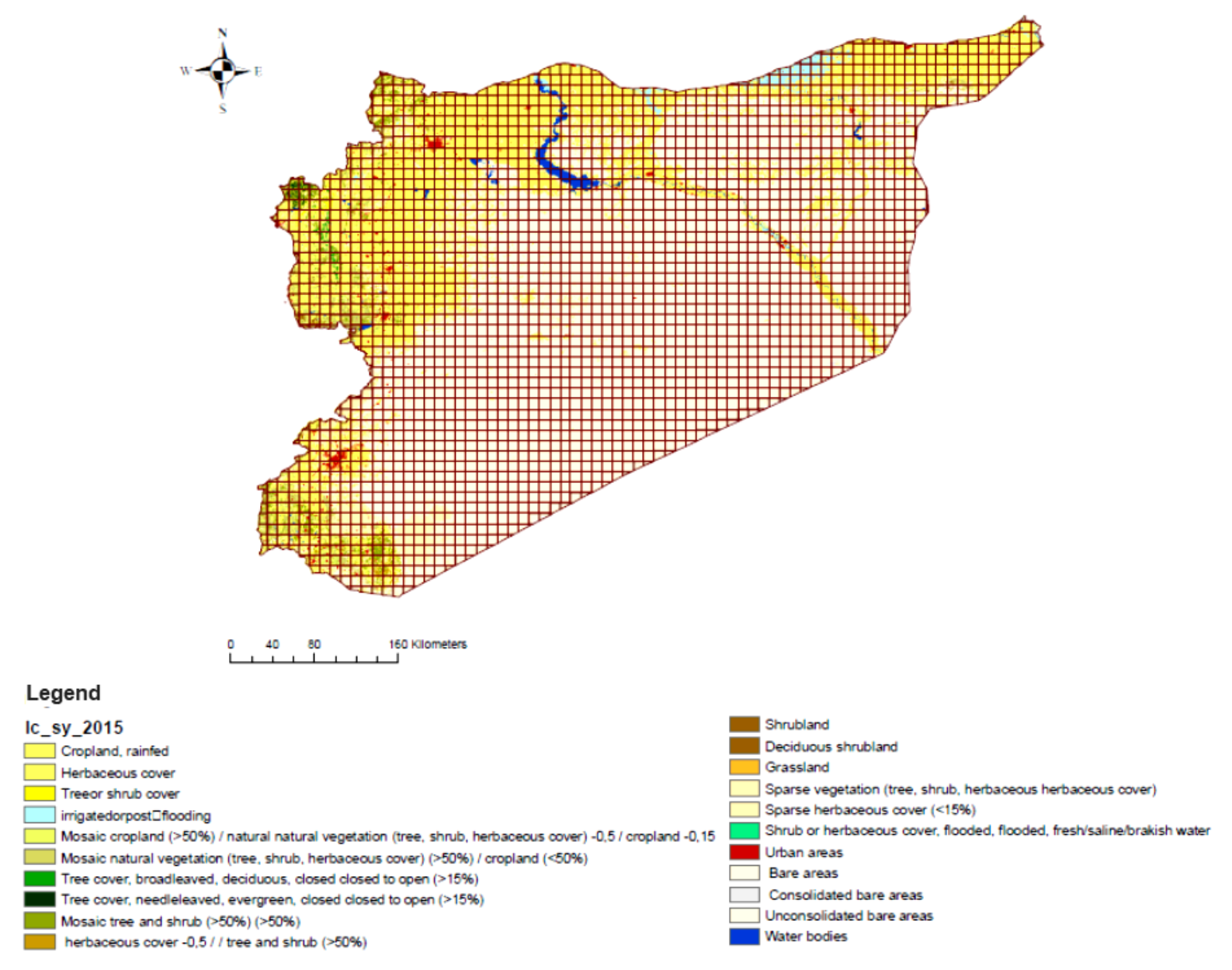

Map3: Land Cover Classification System (LCCS) on 2015 in Syria 


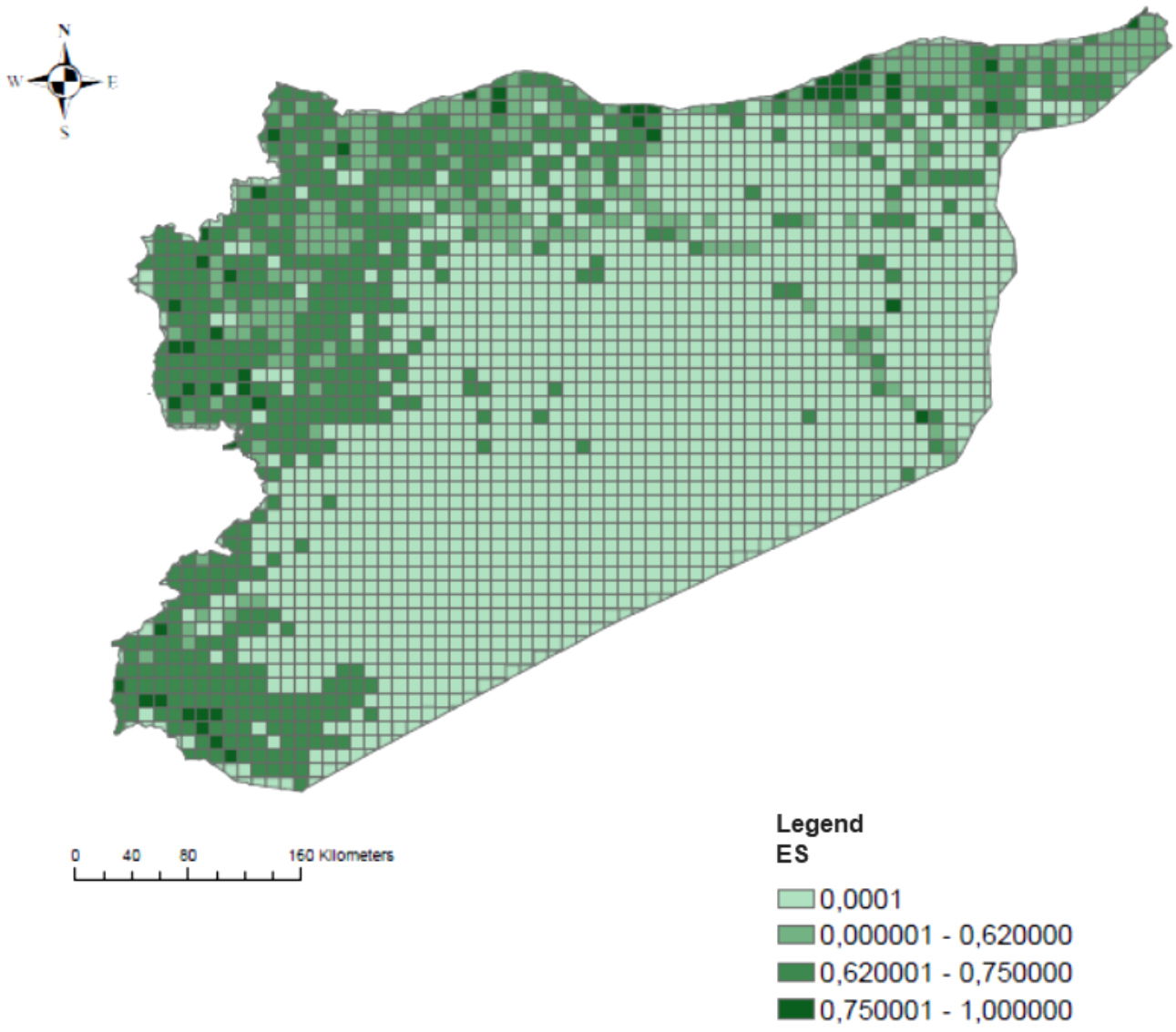

Map 4: Ecological Services Index (ES) Map in Syria

Table 1: value for the Ecological Services Index (ES) assigned to each habitat type

\begin{tabular}{|c|c|c|c|c|c|c|}
\hline Habitat & $\begin{array}{l}\text { Life } \\
\text { Support } \\
\text { Services }\end{array}$ & & $\begin{array}{l}\text { Abstraction } \\
\& \text { Supply } \\
\text { Services }\end{array}$ & $\begin{array}{l}\text { Regulatory } \\
\text { Services }\end{array}$ & $\begin{array}{l}\text { Socio- } \\
\text { Cultural } \\
\text { Services }\end{array}$ & ES \\
\hline 10 Cropland, rainfed & & 1 & 1 & 0,0001 & 1 & 0,750025 \\
\hline 11 Herbaceous cover & & 1 & 0,0001 & 1 & 0,0001 & 0,50005 \\
\hline 12 Tree or shrub cover & & 1 & 0,5 & 1 & 1 & 0,875 \\
\hline $\begin{array}{l}20 \text { Cropland, irrigated or post-flooding } \\
30 \text { Mosaic cropland ( }>50 \% \text { ) / natural } \\
\text { vegetation (tree, shrub, herbaceous }\end{array}$ & & 1 & 1 & 1 & 0,5 & 0,875 \\
\hline $\begin{array}{l}\text { cover) }(<50 \%) \\
40 \text { Mosaic natural vegetation (tree, shrub, } \\
\text { herbaceous cover) }(>50 \%) \text { / cropland }\end{array}$ & & & 1 & 1 & 1 & 1 \\
\hline$(<50 \%)$ & & - & 0,0001 & 1 & 1 & 0,750025 \\
\hline $\begin{array}{l}50 \text { Tree cover, broadleaved, evergreen, } \\
\text { closed to open }(>15 \%)\end{array}$ & & 1 & 0,0001 & 1 & 1 & 0,750025 \\
\hline $\begin{array}{l}60 \text { Tree cover, broadleaved, deciduous, } \\
\text { closed to open }(>15 \%)\end{array}$ & & 1 & 0,0001 & 1 & 1 & 0,750025 \\
\hline $\begin{array}{l}61 \text { Tree cover, broadleaved, } \\
\text { closed }(>40 \%)\end{array}$ & & 1 & 0,0001 & 1 & 1 & 0,750025 \\
\hline
\end{tabular}


62 Tree cover, broadleaved, deciduous, open (15-40\%)

70 Tree cover, needleleaved, evergreen, closed to open (>15\%)

71 Tree cover, needleleaved, evergreen, closed (>40\%)

72 Tree cover, needleleaved, evergreen, open (15-40\%)

80 Tree cover, needleleaved, deciduous, closed to open ( $>15 \%$ )

81 Tree cover, needleleaved, deciduous, closed (>40\%)

82 Tree cover, needleleaved, deciduous, open (15-40\%)

90 Tree cover, mixed leaf type

(broadleaved and needleleaved)

100 Mosaic tree and shrub (>50\%) /

herbaceous cover $(<50 \%)$

110 Mosaic herbaceous cover (>50\%) /

tree and shrub (<50\%)

120 Shrubland

121 Evergreen shrubland

122 Deciduous shrubland

130 Grassland

140 Lichens and mosses

150 Sparse vegetation (tree, shrub, herbaceous cover) $(<15 \%)$

151 Sparse tree $(<15 \%)$

152 Sparse shrub (<15\%)

153 Sparse herbaceous cover $(<15 \%)$

160 Tree cover, flooded, fresh or brakish water

170 Tree cover, flooded, saline water

180 Shrub or herbaceous cover, flooded, fresh/saline/brakish water

190 Urban areas

200 Bare areas

201 Consolidated bare areas

202 Unconsolidated bare areas

210 Water bodies

220 Permanent snow and ice

\begin{tabular}{|c|c|c|c|c|}
\hline 1 & 0,0001 & 1 & 1 & 0,750025 \\
\hline 1 & 0,0001 & 1 & 1 & 0,750025 \\
\hline 1 & 0,0001 & 1 & 1 & 0,750025 \\
\hline 1 & 0,0001 & 1 & 1 & 0,750025 \\
\hline 1 & 0,0001 & 1 & 1 & 0,750025 \\
\hline 1 & 0,0001 & 1 & 1 & 0,750025 \\
\hline 1 & 0,0001 & 1 & 1 & 0,750025 \\
\hline 1 & 0,0001 & 1 & 1 & 0,750025 \\
\hline 1 & 0,0001 & 1 & 1 & 0,750025 \\
\hline 1 & 0,0001 & 1 & 1 & 0,750025 \\
\hline 1 & 0,0001 & 1 & 0,5 & 0,625025 \\
\hline 1 & 0,0001 & 1 & 0,5 & 0,625025 \\
\hline 1 & 0,0001 & 1 & 0,5 & 0,625025 \\
\hline 1 & 0,0001 & 1 & 1 & 0,750025 \\
\hline 0,0001 & 0,0001 & 0,5 & 0,0001 & 0,125075 \\
\hline 1 & 0,0001 & 1 & 1 & 0,750025 \\
\hline 1 & 0,0001 & 1 & 1 & 0,750025 \\
\hline 1 & 0,0001 & 1 & 1 & 0,750025 \\
\hline 1 & 0,0001 & 1 & 1 & 0,750025 \\
\hline 1 & 0,0001 & 1 & 0,0001 & 0,50005 \\
\hline 1 & 0,0001 & 1 & 0,0001 & 0,50005 \\
\hline 1 & 0,0001 & 1 & 0,0001 & 0,50005 \\
\hline 0,0001 & 0,0001 & 0,0001 & 0,0001 & 0,0001 \\
\hline 0,0001 & 0,0001 & 0,0001 & 0,0001 & 0,0001 \\
\hline 0,0001 & 0,0001 & 0,0001 & 0,0001 & 0,0001 \\
\hline 0,0001 & 0,0001 & 0,0001 & 0,0001 & 0,0001 \\
\hline 0,0001 & 0,0001 & 1 & 1 & 0,50005 \\
\hline 0,0001 & 0,0001 & 1 & 0,5 & 0,37505 \\
\hline
\end{tabular}




\section{Environmental Monitoring Index in Armed Conflict Zones (EMC)}

For each of the geographic grid cells, the EMC Index was calculated (Map 5)

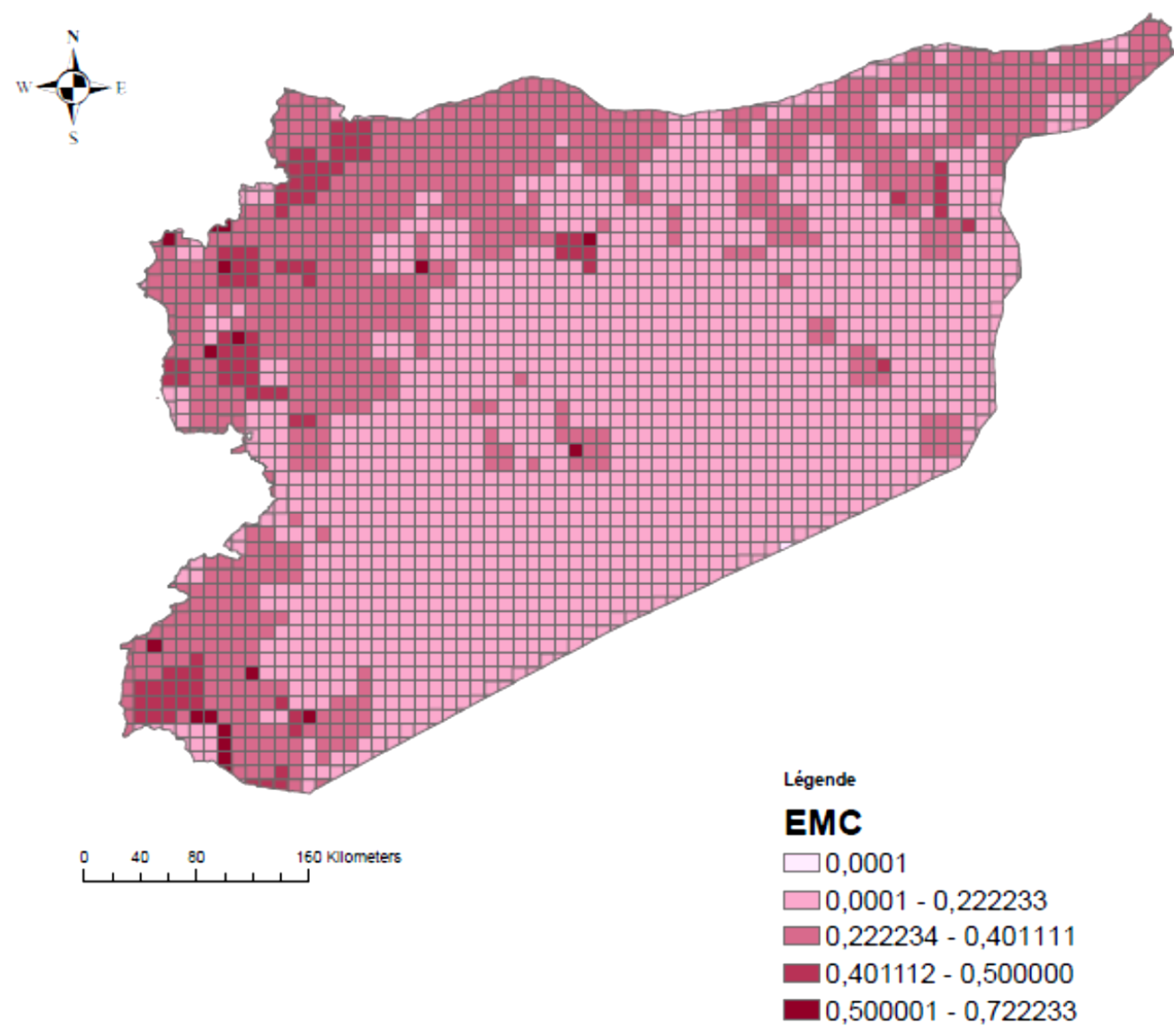

\section{Map5: Environmental Monitoring Index (EMC) Map in Syria}

\section{Analysis and perspective of method used:}

Application of the GIS-EMW method was facilitated by the abundance of existing data on Syria, particularly relating to oil operations, which have been mapped by a number of researchers and journalists, but the same cannot be said for all armed conflict zones around the world.

In this context, this study demonstrated the contributions vis-à-vis the GIS-EMW method made by remote sensing, i.e. the knowledge and techniques whereby certain physical and biological features of location points observed can be determined on the basis of remote measurements, without actually needing to be in physical contact with those location points. (CNRTL Website). 
By example artisanal oil refineries could be visible on satellite images and their environmental impact could be mentioning in armed conflict zones in the absence of other sources of data (Zwijnenburg, 2016).

Many other index can support the model suggested in this study, such as vegetation indexes to identify and measure the vegetation degradation and to detecting and mapping burned surface (Pereira, 1999; Faour et al., 2016)

To develop the use of the contributions of remote sensing in this method, images of the Copernicus Programme of ESA, which delivers optical images SENTINEL2 all the 6 days could be an important tool. SENTINEL2 provides Multi-spectral data with 13 bands in the visible, near infrared, and short wave infrared part of the spectrum with a $10 \mathrm{~m}$ would be an enormous advantage, which allows to follow-up on vast territories. (What is Copernicus, 2018). GIS analysis can be performed with free software also like QGIS also, which has all the good virtues to carry out this work.

The environmental monitoring Index map classes each of the grid cells in Syria according to zone priority in terms of potentially severe damage to the environment, which deprives humans of the resources and services, hitherto - generously - offered. The protection and restoration of such zones is more urgent during and after armed conflicts.

The GIS-EMW model proposed here is flexible and extensible. It is structured in such a way that it can be easily and quickly modified as new data becomes available for each of the geographic grid cells.

This method offers a tool that can be used in all armed conflict zones with a view to creating a useful database for the rehabilitation of those areas and for the management of environmental problems caused by war. This method could be applied to monitor the risk of other events affecting the environment. It can also be used for scientific studies within the numerous fields addressed during and after conflicts.

\section{Acknowledgment:}

We thank Luc Semal, researcher at the Center for Ecology and Conservation Sciences (Cesco, UMR 7204) for his suggestions that significantly contributed to improving the quality of this study. We thank the anonymous reviewers for their helpful and constructive comments that significantly contributed to improving the quality of the publication. 


\section{References:}

1. ACLED. Armed Conflict Location \& Event Data Project. [ONLINE] Available at: https://www.acleddata.com/. Accessed 10 Decembre 2018.

2. Brennan Jacot, M. (2009). Les aires marines protégées comme outils de conservation de la biodiversité marine. Sherbrooke: Université de Sherbrooke.Google Scholar

3. Chechabo Baloko, B. (2011). Impact de la guerre sur l'environnement à l'est de la r.d. congo 2011 (p. 72). Nicosia: Univ Européenne.Google Scholar

4. Di Gregorio, A. (2016). Food and Agriculture Organization of the United Nations, Land Cover Classification System: Classification Concepts and User Manual : LCCS, Version 3 Food \& Agriculture Org, Science - 190 pages.Google Scholar

5. FAO. 2012, (2015), Terms and definitions. Rome.Google Scholar

6. FAO. (2017), Arbres, forêts et utilisation des terres dans les zones arides : première évaluation mondiale. Rome.Google Scholar

7. Faour G., Mhawej M. and Fayad (2016). Detecting Changes in Vegetation Trends in the Middle East and North Africa (MENA) Region Using SPOT Vegetation, Cybergeo: European Journal of Geography [Online], Cartography, Images, GIS, document 779, Online since 14 April 2016, connection on 12 March

2018. https://doi.org/10.4000/cybergeo. 27620

8. Maresca, B., Mordret, X., Ughetto, A.L. and Blancher, P. 2011. Évaluation des services rendus par les écosystèmes en France. Les enseignements d'une application du Millennium Ecosystem Assessment au territoire français, Développement durable et territoires, Vol. 2, $\mathrm{n}^{\circ} 3 \underline{\text { Google Scholar }}$

9. Mobaied, S. (2016). La nature dans les zones de conflits armés. Le cas de la Syrie, Le courrier de la Nature, 299, 42-45. Google Scholar

10. Pereira, J. M. C. (1999). A comparative evaluation of NOAA/AVHRR vegetation indexes for burned surface detection and mapping. IEEE Transactions on Geoscience and Remote Sensing, 37, 217-226.CrossRefGoogle Scholar

11. Rameau, J.C. (1995). Définition et évaluation de la qualité d'un écosystème forestier, in : Actes du Colloque « La bioqualité dans la gestion forestière », 12 sept. (1995, LLN (Belgique), Forêt Wallonne 39/40 38-51.Google Scholar

12. Relief Works Agency (UNRWA). 2018. Map :( Camp and Informal Site Profiles Northeast Syria.Google Scholar 
13. US Department of State Humanitarian Information Unit. (2014). Maps showing the location of refugee camps, [ONLINE] Available

at: https://www.arcgis.com/home/item.html?id=2d256aed15224ccb89971a1b11129c1

8. Accessed 5 Decembre 2018.

14. What is copernicus? [ONLINE] Available

at: https://web.archive.org/web/20181108224549/http://copernicus.eu/main/copernicus -brief. Accessed 25 August 2019.

15. Zwijnenburg, W. 2016. Human health and environmental risks of civilian operated makeshift oil refineries in Syria, PAX Google Scholar 